\title{
PENGARUH METODE LATIHAN DAN KEMAMPUAN GERAK (MOTOR ABILITY) TERHADAP KETERAMPILAN TENDANGAN LURUS PENCAK SILAT
}

\author{
Amalia Barikah ${ }^{1)}$ Endang Pratiwi ${ }^{2)}$ Novri Asri ${ }^{3)}$ \\ ${ }^{1}$ Universitas Islam Kalimantan Muhammad Arsyad Al Banjari Banjarmasin \\ ${ }^{2}$ Universitas Islam Kalimantan Muhammad Arsyad Al Banjari Banjarmasin \\ ${ }^{3}$ Universitas Islam Kalimantan Muhammad Arsyad Al Banjari Banjarmasin \\ Email : ${ }^{1}$ amaliabarikah29@gmail.com, ${ }^{2}$ pratiwiendang@ uniska-bjm-ac-id, \\ nnovriasri.na@gmail.com
}

Tujuan dari penelitian ini adalah untuk menyelidiki dampak dari metode pelatihan (skipping tali usig dan lompat) dan kemampuan motorik pada keterampilan tendangan lurus Pencak Silat. Penelitian ini dilakukan di Ikatan Pencak Silat Indonesia (IPSI) di Kalimantan Selatan menggunakan desain faktorial $2 \times 2$. Analisis ragam antar kelompok berada pada tingkat signifikansi $\alpha=0,05$. Penelitian ini juga bertujuan untuk mengetahui hubungan antara metode pelatihan dan kemampuan motorik terhadap keterampilan tendangan lurus Pencak Silat. Kemampuan Motorik terdiri dari tingkat tinggi dan rendah. Sampel terdiri dari 56 pesilat yang dibagi menjadi empat kelompok, masing-masing kelompok terdiri dari 14 pesilat. Teknik analisis data yang digunakan dalam penelitian ini adalah analisis varians dua arah (ANOVA) dan dilanjutkan dengan uji Tukey pada tingkat signifikansi $\alpha=0,05$. Hasil penelitian ini menunjukkan bahwa (1) secara umum, keterampilan tendangan lurus Pencak Silat yang menggunakan metode latihan lompat tali lebih tinggi daripada yang menggunakan metode lompat pelatihan, (2) untuk kemampuan motorik tinggi yang menggunakan metode latihan lompat tali lebih tinggi daripada yang menggunakan metode lompat pelatihan, (3) untuk kemampuan motorik rendah yang menggunakan lompat tali dan metode lompat pelatihan tidak berbeda pada $\alpha=.05$ tingkat signifikansi, (4) ada hubungan antara metode pelatihan dan kemampuan motorik menuju skill tendangan lurus Pencak Silat.

\section{Kata Kunci : Metode Latihan Kemampuan gerak, Tendangan Lurus}

\section{Abstract}

The objective of this research is to investigate the impact of training methods (usig rope skipping and hop jump) and motor ability on Pencak Silat straight kick skill. This research is conducted at Pencak Silat Indonesian (IPSI) in south Borneo, using 2 $x 2$ factorial design. The analysis of variance between groups is at level of significance $\alpha$ $=0,05$. This research also aimed to find out the relationship between training methods and motor ability toward Pencak Silat straight kick skill. Motor Ability consists of hight and low levels. The sample consists of 56 pesilat who are divided into four groups, each group consists of 14 pesilat. The data analysis techniques use in this research were twoway analyses of variance (ANOVA) and further continued by Tukey test at $\alpha=.05$ level of significance. The results of this research show that (1) in general, Pencak Silat straight kick skill which uses rope skipping training method is higher than that which uses hop jump training method, (2) 


\section{PENDAHULUAN}

Pencak Silat sebagai cabang olahraga yang memerlukan aspek fisik untuk melaksanakan aktivitasnya, pencak silat juga mengembangkan hubungan ketiga komponen kekuatan, daya tahan dan kecepatan menjadi komponen utama. Dalam pelaksanannya, struktur teknik pencak silat terdiri atas empat bagian yaitu; (1) sikap pasang. (2) pola langkah, (3) serangan-belaan, dan (4) kembali ke sikap pasang. Keempat pola tersebut merupakan suatu kesatuan gerak yang membentuk suatu rangkaian gerak sehingga menjadi pola gerak tertentu.(Notosoejitno, Khasanah, 1997:2)

Pada saat ini, penguasaan kemampuan keterampilan tendangan lurus pada pesilat KPS Nusantara khususnya Pesilat KPS Nusantara Provinsi Kalimantan Selatan, dirasakan kurang maksimal. Ini dapat penulis rasakan setiap memberikan latihan kepada mereka. Berdasarkan hasil analisis penulis banyak faktor yang mengakibatkan kurang maksimalnya penguasaan keterampilan tendangan lurus tersebut, mulai dari dalam diri pesilat tersebut sampai dengan faktor dari luar diri pesilat. Mengingat betapa pentingnya penguasaan tendangan lurus tersebut, maka penulis menganalisis bahwa faktor metode latihan yang diberikan oleh pelatih merupakan faktor yang sangat penting untuk diperhatikan. Berdasarkan hal tersebut maka dirasa perlu dicarikan metode latihan yang tepat untuk melatih keterampilan tendangan lurus, dua diantaranya adalah metode latihan hop jump dan skipping rope.

Latihan hop jump dan skipping rope adalah bentuk metode latihan yang diantaranya bertujuan untuk melatih otot-otot tungkai kaki. Dengan mengetahui fungsi otot yang bekerja pada waktu menendang lurus akan memudahkan dalam melatih keterampilan tendangan lurus. Kedua bentuk latihan selain mengetahui fungsi otot yang bekerja juga melibatkan kerja otot-otot tersebut sehingga hasil latihan ini dapat memberikan suatu pengaruh yang diharapkan.

\section{METODE}

Dengan demikian hal ini dapat dijadikan pegangan bagi para pelatih, pengurus dan dan pembina olahraga pencak silat guna pelaksanaan pelatihan secara efisien dan efektif.

Metode yang dipergunakan dalam penelitian ini adalah metode eksperimen lapangan. Winarno : 2011 menyatakan metode eksperimen lapangan adalah metode yang hendak menemukan faktorfaktor sebab akibat, mengontrol peristiwa-peristiwa dalam interaksi variabel-variabel serta meramalkan hasil-hasilnya pada tingkat ketelitian tertentu.

Penelitian ini bertujuan untuk mengetahui salah satu diantara dua metode latihan yaitu hop jump dan skipping rope yang lebih berpengaruh terhadap keterampilan tendangan lurus pencak silat. Perkembangan olahraga pencak silat yang merupakan bagian dari cabang olahraga seni dan beladiri serta untuk lebih mempopulerkan di kalangan club / perguruan pencak silat, maka memerlukan adanya suatu wadah penyaluran bakat tersebut, tentu saja melalui berbagai proses, salah satu diantaranya dengan mempertandingkan kejuaraan daerah pencak silat.

Tabel 1. Rancangan Faktorial $2 \times 2$

\begin{tabular}{l|c|c|} 
Metodelatihan & $\begin{array}{c}\text { Skipping } \\
\text { rope } \\
\left(\mathrm{A}_{1}\right)\end{array}$ & $\begin{array}{c}\text { Hop jump } \\
\left(\mathrm{A}_{2}\right)\end{array}$ \\
(A) & \\
Kemampuan \\
(motor ability) \\
(B)
\end{tabular}




\begin{tabular}{|c|c|c|}
\hline $\begin{array}{c}\text { Kemampuan } \\
\text { Gerak (motor } \\
\text { ability) Tinggi } \\
\left(\mathrm{B}_{1}\right)\end{array}$ & $\mathrm{A}_{1} \mathrm{~B}_{1}$ & $\mathrm{~A}_{2} \mathrm{~B}_{1}$ \\
\hline $\begin{array}{c}\text { Kemampuan } \\
\text { Gerak (motor } \\
\text { ability) Rendah } \\
\left(\mathrm{B}_{2}\right)\end{array}$ & $\mathrm{A}_{1} \mathrm{~B}_{2}$ & $\mathrm{~A}_{2} \mathrm{~B}_{2}$ \\
\hline Total & $\mathrm{A}_{1}$ & $\mathrm{~A}_{2}$ \\
\hline
\end{tabular}

\section{Populasi dan Sampel}

Untuk menentukan kategori tinggi dan rendahnya kemampuan gerak (motor ability) pada masing-masing kelompok yang berjumlah 56 orang, dilakukan tes kepada anggota kelompok. Hasil tes dari masing-masing anggota kelompok disusun menurut skor nilai yang diperoleh yaitu mulai dari skor tertinggi sampai skor yang paling rendah. Verducci menyatakan bahwa untuk menentukan kategori tinggi rendahnya suatu skor, dapat dilakukan dengan cara membagi anggota subjek dengan teknik persentase. Teknik persentase yang dimaksud yaitu 27\% untuk batas atas yang mewakili nilai tertinggi dan $27 \%$ untuk batas bawah yang mewakili nilai terendah dari masing-masing kelompok.(Frank M. Verducci, Measurement Concepts in Physical education 1980: 176)

Jumlah sampel masing-masing kelompok sebanyak 28 orang yang terdiri dari 14 orang skor tertinggi $(27 \%$ dari 50) dan 14 orang dari skor terendah (27\% dari 50). Sedangkan anggota sampel yang skornya berada diantara kedua kategori tersebut tidak dilibatkan dalam penelitian, sehingga secara keseluruhan jumlah sampel yang terlibat dalam penelitian ini sebanyak 56 orang, yang tergabung dalam empat kelompok perlakuan. Keempat kelompok perlakuan yang dimaksud yaitu : dua dari kelompok metode latihan skipping rope dengan kemampuan gerak (motor ability) tinggi dan rendah dan dua dari kelompok metode latihan hop jump dengan kemampuan gerak (motor ability) tinggi dan rendah.

\section{Data, Instrumen, dan Teknik Pengumpulan Data \\ Dalam melakukan suatu} penelitian langkah pertama yang perlu dilakukan adalah mempersiapkan dan menetapkan instrumen. Sesuai dengan variabel yang dilibatkan dalam penelitian, maka instrumen yang digunakan dalam pengumpulan data terdiri dari dua jenis tes, yaitu : (1) tes kemampuan gerak (motor ability). (2). Tes kecepatan tendangan lurus.

\section{Penelitian}

$$
\text { Pengelompokan Subjek }
$$

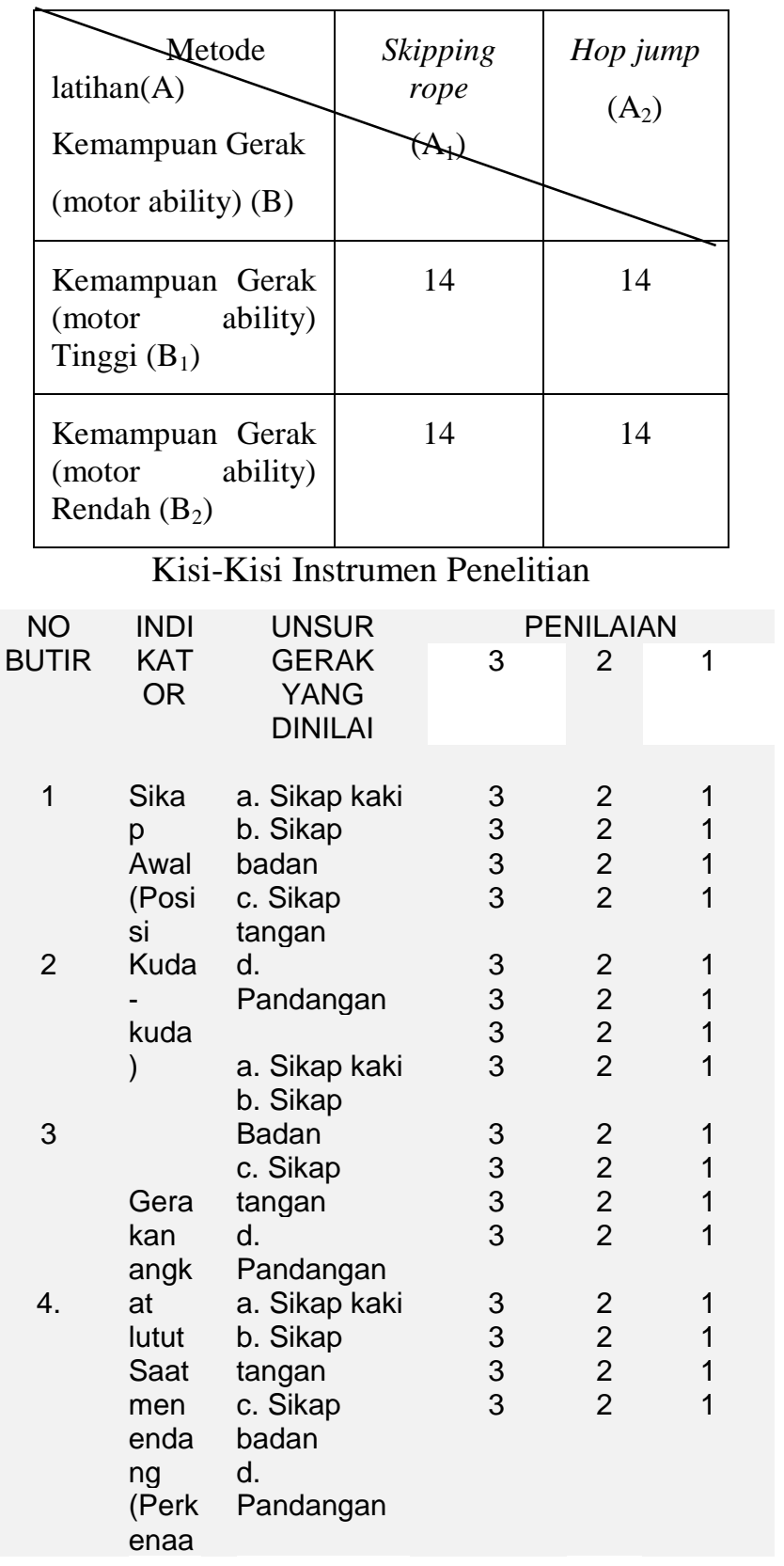




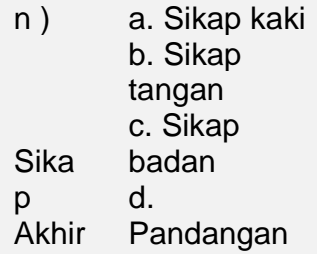

\section{HASIL DAN PEMBAHASAN}

Sebelum dilakukan analisis Varian (Anava), terlebih dahulu dilakukan uji persyaratan analisis, yaitu (1) uji normalitas; dan (2) uji homigenitas populasi.

\section{Uji Normalitas}

Uji normalitas skor hasil ketrampilan tendangan lurus pencak silat dilakukan dengan menggunakan uji Liliefors pada taraf signifikan $\alpha=$ 0,05 . Ringkasan hasil uji normalitas sampel dapat dilihat pada halaman 149. Perhitungan dapat dilihat pada lampiran 7.

Tabel 2. Rangkuman hasil uji normalitas sampel

\begin{tabular}{llllll|}
$\begin{array}{l}\text { Kelomp } \\
\text { ok }\end{array}$ & N & $\mathrm{L}_{0}$ & $\mathrm{~L}_{\mathrm{t}}$ & $\begin{array}{l}\text { Kesimpul } \\
\text { an }\end{array}$ \\
\hline $\mathbf{1}$ & $\mathbf{2}$ & $\mathbf{0 , 1 5}$ & $\mathbf{0 , 2 2}$ & Normal \\
$\mathbf{2}$ & $\mathbf{8}$ & $\mathbf{6}$ & $\mathbf{0}$ & Normal \\
$\mathbf{3}$ & $\mathbf{2}$ & $\mathbf{0 , 1 5}$ & $\mathbf{0 , 2 2}$ & Normal \\
$\mathbf{4}$ & $\mathbf{8}$ & $\mathbf{6}$ & $\mathbf{0}$ & Normal \\
$\mathbf{5}$ & $\mathbf{1}$ & $\mathbf{0 , 2 1}$ & $\mathbf{0 , 2 5}$ & Normal \\
$\mathbf{6}$ & $\mathbf{4}$ & $\mathbf{6}$ & $\mathbf{8}$ & Normal \\
& $\mathbf{1}$ & $\mathbf{0 , 2 4}$ & $\mathbf{0 , 2 5}$ & \\
& $\mathbf{4}$ & $\mathbf{4}$ & $\mathbf{8}$ & \\
& $\mathbf{1}$ & $\mathbf{0 , 2 2}$ & $\mathbf{0 , 2 5}$ & \\
$\mathbf{4}$ & $\mathbf{6}$ & $\mathbf{8}$ & \\
& $\mathbf{1}$ & $\mathbf{0 , 1 8}$ & $\mathbf{0 , 2 5}$ & \\
$\mathbf{4}$ & $\mathbf{5}$ & $\mathbf{8}$ & \\
& & & & \\
& & &
\end{tabular}

\section{Keterangan:}

Kelompok 1 = Kelompok metode latihan skipping rope secara keseluruhan

Kelompok 2 = Kelompok metode latihan hop jump secara Keseluruhan

Kelompok 3 = Kelompok kemampuan gerak (motor ability) tinggi dengan metode Latihan skipping rope

Kelompok $4=$ Kelompok

kemampuan gerak (motor ability) rendah dengan metode latihan skipping rope

Kelompok $5=$ Kelompok

kemampuan gerak (motor ability) tinggi dengan metode latihan hop jump

Kelompok $6=$ Kelompok

kemampuan gerak (motor ability) rendah dengan metode latihan hop jump.

\begin{tabular}{lllrll} 
S.Variasi & dk & JK & \multicolumn{1}{l}{ KT } & Fo & Ft \\
$\begin{array}{llrrr}\text { Rata-rata } \\
\text { Perlakuan }\end{array}$ & 1 & 69583,5 & & & \\
$\quad$ A & 1 & 48,28 & 48,28 & 4,26 & $\mathbf{4 , 1 1}$ \\
$\quad$ B & 1 & 301,71 & 301,71 & & $\mathbf{4 , 1 1}$ \\
$\quad$ AB & 1 & 1112,5 & 21,39 & 32,07 & $\mathbf{4 , 1 1}$ \\
Kekeliruan & 52 & & & & \\
& & & & 14,11 & \\
\hline
\end{tabular}

$\begin{array}{lll}\text { Jumlah } & 56 & \mathbf{7 1 7 3 2}\end{array}$

Hasil perhitungan sebagaimana digambarkan pada lampiran 7, diperoleh $\mathrm{L}_{\mathrm{o}}$ untuk seluruh kelompok sampel lebih kecil dibanding dengan $\mathrm{L}_{\mathrm{t}}$. Dengan demikian dapat disimpulkan bahwa sampel berasal dari populasi berdistribusi normal.

\section{Uji Homogenitas}

Uji homigenitas menggunakan uji Bartlett dengan taraf signifikansi $\alpha=$ 0,05 . Ringkasan hasil uji homogenitas dapat dilihat pada lampiran 8 halaman 157.

Tabel 3. Rangkuman hasil uji homogenitas

\begin{tabular}{|c|c|c|c|c|c|}
\hline Kel & Variansi & V.Gab & $\mathrm{X}_{\mathrm{h}}^{2}$ & $X_{t}^{2}$ & $\begin{array}{l}\text { Kesim } \\
\text { pulan }\end{array}$ \\
\hline 1 & 12.60 & \multirow{4}{*}{21.367} & \multirow{4}{*}{5.48} & \multirow{4}{*}{7,81} & \multirow{4}{*}{$\begin{array}{l}\text { Homo } \\
\text { gen }\end{array}$} \\
\hline 2 & 32.83 & & & & \\
\hline 3 & 11.63 & & & & \\
\hline 4 & 28.41 & & & & \\
\hline \multicolumn{6}{|c|}{ Keterangan: } \\
\hline \multirow{2}{*}{\multicolumn{2}{|c|}{ Kelompok 1}} & \multicolumn{3}{|c|}{$=$ Kelompok } & \\
\hline & & $\begin{array}{l}\text { kemam } \\
\text { (motor }\end{array}$ & $\begin{array}{l}\text { lan } \\
\text { bility) }\end{array}$ & $\begin{array}{l}\text { gerak } \\
\text { tinggi }\end{array}$ & \\
\hline
\end{tabular}


dengan metode latihan skipping rope

Kelompok 2 Kelompok

kemampuan gerak (motor ability) rendah dengan metode latihan skipping rope

Kelompok 3 = Kelompok

kemampuan gerak (motor ability) tinggi dengan metode latihan hop jump.

Kelompok 4 = Kelompok kemampuan gerak (motor ability) rendah dengan metode latihan hop jump

$\mathbf{X}_{\mathbf{h}}^{\mathbf{2}}=$ Harga Chi-kuadrat $\mathbf{X}^{\mathbf{2}}{ }_{\mathbf{t}}=\begin{aligned} & \text { hitung } \\ & \text { Harga }\end{aligned}$ tabel

Hasil perhitungan sebagaimana digambarkan pada tabel 13 di atas, diperoleh $\mathrm{X}_{\mathrm{h}}^{2}=5.48$ lebih kecil dibanding dengan $\mathrm{X}_{\mathrm{t}}^{2}=7,81$ Sehingga Ho: $\sigma^{2} 1=\sigma^{2} 2=\sigma^{2} 3=\sigma^{2} 4$ diterima dalam taraf nyata $\alpha=0,05$. Dengan demikian dapat disimpulkan bahwa keempat populasi mempunyai varians yang sama besar (homogen).

\section{Pengujian Hipotesis}

Untuk menguji hipotesis satu dan dua digunakan teknik analisis varian (ANAVA) dua jalur. Perhitungan ANAVA secara lengkat dapat dilihat pada lampiran 10 halaman 165. Rangkumannya pada tabel $4.13 \mathrm{di}$ bawah ini.

Tabel 4. Ringkasan hasil perhitungan Anava skor keterampilan tendangan lurus pencak silat pada taraf $\alpha=0,05$.

Keterangan:

$$
\begin{aligned}
* & =\text { signifikan pada taraf nyata } \alpha= \\
0,05 . & \\
\mathrm{dk} & =\text { derajat kebebasan } \\
\mathrm{JK} & =\text { jumlah kuadrat } \\
\mathrm{KT} & =\text { rata-rata jumlah kuadrat } \\
\mathrm{Fo} & =\text { harga } \mathrm{F} \text { observasi } \\
\mathrm{Ft} & =\text { harga } \mathrm{F} \text { tabel }
\end{aligned}
$$

\section{Perbedaan peningkatan keterampilan tendangan lurus pencak silat antara metode latihan skipping rope dengan metode latihan hop jump secara keseluruhan}

Berdasarkan hasil analisis varian (ANAVA) pada taraf signifikan $\alpha=$ 0,05, didapat $F_{h}=14,11$ dan $F_{t}=4,11$. Rangkumannya dapat dilihat pada lampiran 10 halaman 167. Dengan demikian $\mathrm{F}_{\mathrm{o}}>\mathrm{F}_{\mathrm{t}}$, sehingga $\mathrm{H}_{\mathrm{o}}$ ditolak, sehingga dapat disimpulkan bahwa secara keseluruhan, terdapat perbedaan yang nyata antara metode latihan skippping rope dan hop jump terhadap hasil keterampilan tendangan lurus pencak silat. Dengan perkataan lain bahwa hasil keterampilan tendangan lurus pencak silat dengan menggunakan metode latihan skipping rope $(\bar{X}=$ 36,18; sd $=6,84$ ) lebih baik dari pada metode latihan hop jump ( $\bar{X}=34.32$; s $=5.56)$. Ini berarti hipotesis penelitian yang menyatakan bahwa secara keseluruhan keterampilan tendangan lurus pencak silat dengan menggunakan metode latihan skipping rope lebih baik dibanding dengan menggunakan metode latihan hop jump teruji.

\section{Perbedaan peningkatan keterampilan tendangan lurus pencak silat antara metode latihan skipping rope dan hop jump bagi kelompok kemampuan gerak (motor ability) tinggi}

Metode latihan skipping rope dan hop jump memberikan perbedaan yang signifikan terhadap hasil keterampilan tendangan lurus pencak silat lantai bagi kelompok yang memiliki kemampuan gerak (motor ability) tinggi. Hal ini terbukti berdasarkan hasil uji lanjut dengan menggunakan uji Tukey yang hasilnya sebagai berikut:

Tabel 5. Perbandingan kelompok metode latihan skipping rope dan hop jump pada 
kemampuan gerak (motor ability) tinggi.

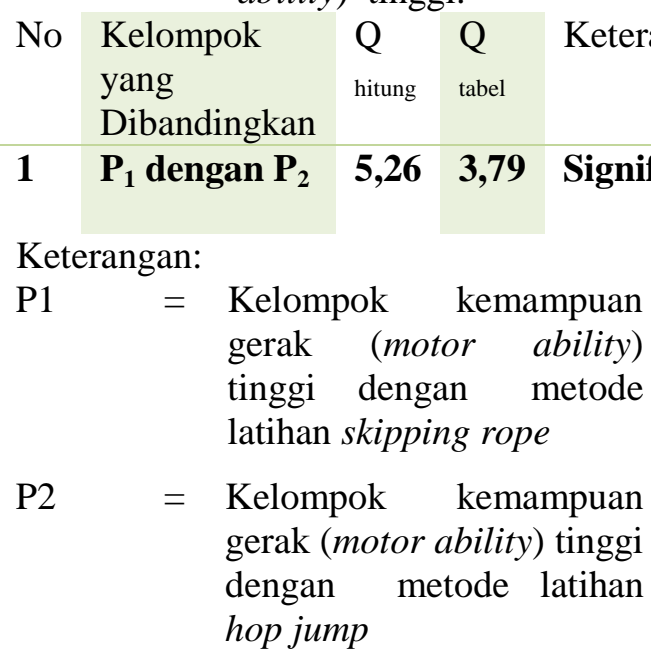

Kelompok kemampuan gerak (motor ability) tinggi dengan metode latihan skipping rope $\left(\mathrm{P}_{1}\right)$ dibanding dengan kelompok kemampuan gerak (motor ability) tinggi dengan metode latihan hop jump $\left(\mathrm{P}_{2}\right)$, diperoleh $\mathrm{Q}_{\mathrm{h}}=$ 5,26 dan $\mathrm{Q}_{\mathrm{t}}=3,79$. Dengan demikian $\mathrm{Q}_{\mathrm{h}}$ lebih besar dari $\mathrm{Q}_{\mathrm{t}}$, sehingga Ho ditolak. Kesimpulan, bagi pesilat yang memiliki kemampuan gerak (motor ability) tinggi, hasil keterampilan tendangan lurus pencak silat dengan metode latihan skipping rope $(\bar{X}=42$, dan $\mathrm{S}=3.65$ ) lebih baik dari metode latihan hop jump ( $\bar{X}=35,5$ dan $\mathrm{S}=3,55$ ).

3. Perbedaan

peningkatan keterampilan tendangan lurus pencak silat antara metode latihan skipping rope dan hop jump bagi kelompok kemampuan gerak (motor ability) rendah

Metode latihan skipping rope dan hop jump memberikan perbedaan terhadap hasil keterampilan tendangan lurus pencak silat bagi kelompok yang memiliki kemampuan gerak (motor ability) rendah, namun perbedaan hasil tersebut tidak signifikan. Hal ini terbukti berdasarkan hasil uji lanjut dengan menggunakan uji Tukey yang hasilnya sebagai berikut:

Tabel 6.. Perbandingan kelompok metode latihan skipping rope dan hop jump bagi kelompok kemampuan gerak (motor ability) rendah.

\begin{tabular}{|c|c|c|c|c|}
\hline \multirow[t]{2}{*}{ No } & \multirow{2}{*}{$\begin{array}{l}\text { Kelompok } \\
\text { yang } \\
\text { Dibanding } \\
\text { kan }\end{array}$} & & \multirow[t]{2}{*}{$\begin{array}{l}\mathrm{Q} \\
\text { tabel }\end{array}$} & \multirow[t]{2}{*}{$\begin{array}{l}\text { Keterang } \\
\text { an }\end{array}$} \\
\hline & & $\mathrm{g}$ & & \\
\hline 2 & $\begin{array}{l}\mathbf{P}_{4} \\
\text { dengan } \\
\mathbf{P}_{3}\end{array}$ & $\begin{array}{l}2,2 \\
5\end{array}$ & $\begin{array}{l}3,7 \\
9\end{array}$ & $\begin{array}{l}\text { Tidak } \\
\text { Signifik } \\
\text { an }\end{array}$ \\
\hline
\end{tabular}

Keterangan:
P4 = Kelompok kemampuan gerak (motor ability) rendah dengan metode latihan hop jump.
P3 = Kelompok kemampuan gerak (motor ability) rendah dengan metode latihan skipping rope.

Kelompok kemampuan gerak (motor ability) rendah dengan metode latihan hop jump $\left(\mathrm{P}_{4}\right)$ dibanding dengan kelompok kemampuan gerak (motor ability) rendah dengan metode latihan skipping rope $\left(\mathrm{P}_{3}\right)$, diperoleh hasil, $\mathrm{Q}_{\mathrm{h}}=$ $2,25<\mathrm{Q}_{\mathrm{t}}=3,79$. Artinya, Ho diterima, dan $\mathrm{H}_{1}$ ditolak. Dengan demikian dapat dikatakan bahwa bagi kelompok kemampuan gerak (motor ability) rendah, hasil keterampilan tendangan lurus pencak silat yang dilatih dengan metode latihan hop jump ( $\bar{X}=33.14 ; \mathrm{s}$ $=5,33)$ dan skipping rope $(\bar{X}=30.36 ; \mathrm{s}$ $=3.41)$ tidak memberikan perbedaan yang signifikan pada taraf $\alpha$ : 0,05.

4. Pengaruh Interaksi antara metode latihan dan kemampuan gerak (motor ability) terhadap hasil keterampilan tendangan lurus pencak silat.

Berdasarkan hasil analisis varian dua arah, interaksi antara metode latihan dan kemampuan gerak (motor ability) terhadap hasil keterampilan tendangan lurus pencak silat terlihat pada tabel perhitungan anava di atas. Harga hitung Fo interaksi $(\mathrm{FAB})=14,11$ dan $\mathrm{F}$ tabel =4.11. Tampak bahwa $\mathrm{F}$ hitung $>\mathrm{F}$ tabel, sehingga $\mathrm{H}_{0}$ ditolak. dan $\mathrm{H}_{1}$ diterima. Dengan demikian dapat 
disimpulkan bahwa terdapat interaksi antara metode latihan dan kemampuan gerak (motor ability) terhadap hasil keterampilan tendangan lurus pencak silat.

Berdasarkan data hasil penelitian, diperoleh skor rata-rata keterampilan tendangan lurus pencak silat kelompok kemampuan gerak (motor ability) tinggi yang dilatih dengan metode latihan skipping rope adalah sebesar 42 dan kelompok kemampuan gerak (motor ability) rendah adalah sebesar 30,36. Untuk skor rata-rata keterampilan tendangan lurus Pencak silat kelompok kemampuan gerak (motor ability) tinggi yang dilatih dengan metode latihan hop jump adalah sebesar 35,50 dan kelompok kemampuan gerak (motor ability) rendah adalah sebesar 33,14.

Dengan demikian hipotesis penelitian keempat yang menyatakan terdapat interaksi antara metode latihan dan kemampuan gerak (motor ability) terhadap keterampilan tendangan lurus pencak silat teruji.

Interaksi metode latihan dan kemampuan gerak (motor ability) terhadap keterampilan tendangan lurus pencak silat dapat dilihat pada Gambar 8.

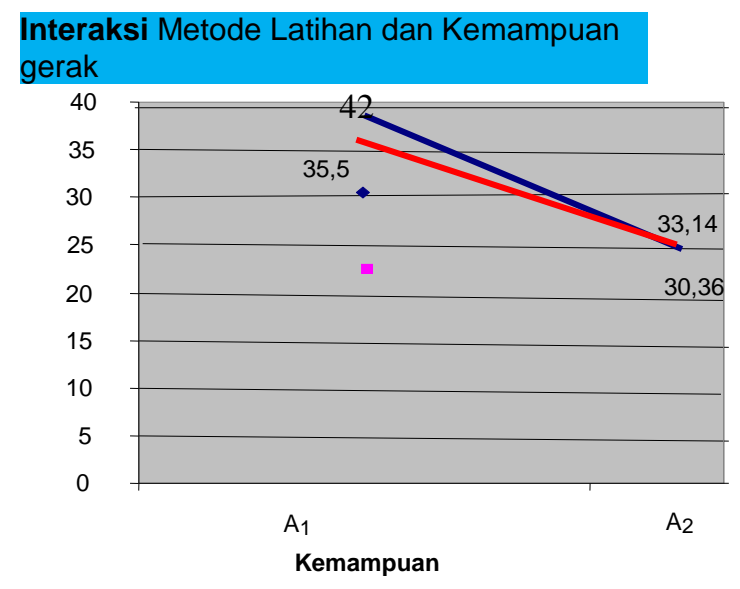

Gambar 1 Interaksi Metode Latihan Dengan kemampuan gerak

Sumber : Hasil Pengolahan

Data Melalui Anava 2x2

Keteranqan:

$\mathrm{A}_{1}=$ Metode latihan skipping rope
$\mathrm{A}_{2} \quad=$ Metode latihan hop jump

Setelah dilakukan analisis data dengan menggunakan pendekatan analisis varians (ANAVA) dan dilanjutkan dengan uji Tukey, maka pembahasan hasil penelitian akan terpusat pada empat hipotesis yang telah diuji kebenarannya yaitu sebagai berikut

Secara keseluruhan, hasil keterampilan tendangan lurus pencak silat melalui penerapan metode latihan skipping rope (A1) lebih baik daripada metode latihan hopjump (A2)

Keterampilan tendangan lurus pencak silat merupakan salah satu pola gerak dasar yang sangat penting pada pencak silat. Setiap pesilat harus benarbenar menguasai akan pola gerak dasar tendangan lurus pencak silat. Untuk itu dibutuhkan metode latihan yang cocok di dalam melatih keterampilan teknik tendangan lurus pencak silat. Dalam penelitian ini diterapkan dua metode latihan, yakni metode latihan skipping rope dan metode latihan hop jump dengan tujuan untuk melihat metode mana yang lebih baik dalam meningkatkan keterampilan tendangan lurus pencak silat.

Kedua metode latihan ini mempunyai tujuan yang sama yaitu meningkatkan keterampilan tendangan lurus pencak silat yang mana kemampuan gerak (motor ability) tersebut sangat menunjang untuk mendapatkan keterampilan tendangan lurus pencak silat yang baik, akan tetapi masing-masing metode latihan tersebut memiliki perbedaan dalam segi pelaksanaannya.

Hasil analisis gerak di atas diperkuat oleh hasil perhitungan analisis varians tentang perbedaan keefektifan antara kedua metode latihan secara keseluruhan, yakni; $\mathrm{F}$ observasi antar kolom $(\mathrm{FA})=4,94$, lebih besar daripada F tabel, yaitu sebesar 4,11 (Fo = 4,94 > $\mathrm{Ft}=4,11$ ), dan dengan melihat hasil keterampilan tendangan luruspPencak silat menggunakan metode latihan 
skipping rope $(=36,180$ dan $\mathrm{s}=6,84)$ dibandingkan hasil keterampilan tendangan lurus pencak silat menggunakan metode latihan hop jump ( $=34,32$ dan $\mathrm{s}=5,56$ ), maka dapat disimpulkan bahwa secara keseluruhan metode latihan skipping rope lebih baik daripada metode latihan hop jump terhadap hasil keterampilan tendangan lurus pencak silat.

Dengan demikian berdasarkan pembahasan hasil penelitian, maka dapat direkomendasikan bahwa metode latihan skipping rope lebih cocok diterapkan dalam meningkatkan keterampilan tendangan lurus Pencak silat.

1. Secara keseluruhan, hasil keterampilan tendangan lurus pencak silat melalui penerapan metode latihan skipping rope (A1) lebih baik daripada metode latihan hopjump (A2).

Keterampilan tendangan lurus pencak silat merupakan salah satu pola gerak dasar yang sangat penting pada pencak silat. Setiap pesilat harus benarbenar menguasai akan pola gerak dasar tendangan lurus pencak silat. Untuk itu dibutuhkan metode latihan yang cocok di dalam melatih keterampilan teknik tendangan lurus pencak silat. Dalam penelitian ini diterapkan dua metode latihan, yakni metode latihan skipping rope dan metode latihan hop jump dengan tujuan untuk melihat metode mana yang lebih baik dalam meningkatkan keterampilan tendangan lurus pencak silat.

Kedua metode latihan ini mempunyai tujuan yang sama yaitu meningkatkan keterampilan tendangan lurus pencak silat yang mana kemampuan gerak (motor ability) tersebut sangat menunjang untuk mendapatkan keterampilan tendangan lurus pencak silat yang baik, akan tetapi masing-masing metode latihan tersebut memiliki perbedaan dalam segi pelaksanaannya.

Hasil analisis gerak di atas diperkuat oleh hasil perhitungan analisis varians tentang perbedaan keefektifan antara kedua metode latihan secara keseluruhan, yakni; $\mathrm{F}$ observasi antar kolom $(\mathrm{FA})=4,94$, lebih besar daripada F tabel, yaitu sebesar 4,11 (Fo $=4,94>$ $\mathrm{Ft}=4,11$ ), dan dengan melihat hasil keterampilan tendangan luruspPencak silat menggunakan metode latihan skipping rope ( $=36,180$ dan $\mathrm{s}=6,84$ ) dibandingkan hasil keterampilan tendangan lurus pencak silat menggunakan metode latihan hop jump ( 薏 $=34,32$ dan $\mathrm{s}=5,56$ ), maka dapat disimpulkan bahwa secara keseluruhan metode latihan skipping rope lebih baik daripada metode latihan hop jump terhadap hasil keterampilan tendangan lurus pencak silat.

Dengan demikian berdasarkan pembahasan hasil penelitian, maka dapat direkomendasikan bahwa metode latihan skipping rope lebih cocok diterapkan dalam meningkatkan keterampilan tendangan lurus Pencak silat.

2. Terdapat interaksi antara metode latihan dengan kemampuan gerak (motor ability) terhadap hasil keterampilan tendangan lurus Pencak silat.

Hasil analisis varians $2 \times 2$, tentang interaksi antara metode latihan dengan kemampuan gerak (motor ability) terhadap keterampilan tendangan lurus Pencak silat menunjukkan bahwa Fobservasi = 14,11> Ftabel $0,05=4,11$. Interaksi ini menggambarkan bahwa metode latihan skipping rope lebih cocok diterapkan bagi pesilat yang memiliki kemampuan gerak (motor ability) tinggi dibandingkan dengan metode latihan hop jump: A1B1 > A2B1. Sebaliknya, metode latihan hop jump dan skipping rope samasama dapat diterapkan bagi pesilat yang memiliki kemampuan gerak (motor ability) rendah. Hal ini diperkuat oleh hasil uji lanjut yang membedakan antara metode latihan skipping rope dengan kemampuan gerak (motor ability) tinggi dan 
metode latihan hop jump dengan kemampuan gerak (motor ability) tinggi; A1B1 : A2B1 (P1 : P2), hasil Qhitung 5,26 > Qtabel 3,79. Dengan kata lain keefektifan metode latihan skipping rope dengan kemampuan gerak (motor ability) tinggi ( $=42$ dan $s d=3,65)$ lebih baik secara nyata dibandingkan dengan metode latihan hop jump ( $=35,5$ dan $\mathrm{sd}=$ 3,55). Metode latihan hop jump dengan kemampuan gerak (motor ability) rendah dan metode latihan skipping rope dengan kemampuan gerak (motor ability) rendah; A2B2 : A1B2 (P4 : P3), hasil Qhitung 2,25 $>$ Qtabel 3,79. Dengan kata lain metode latihan hop jump ( $=33,14$ dan $\mathrm{sd}=5,33$ ) dan metode latihan skipping rope $($ 罍 $=30,36$ dan $\mathrm{sd}=$ 3,41 ), keduanya sama-sama memberikan keefektifan hasil terhadap keterampilan tendangan lurus Pencak silat.

Dengan demikian dapat disimpulkan bahwa bagi pesilat yang memiliki kemampuan gerak (motor ability) tinggi jika ingin meningkatkan keterampilan tendangan lurus Pencak silat hendaknya dilatih dengan menggunakan metode latihan skipping rope, sebaliknya bagi pesilat yang memiliki kemampuan gerak (motor ability) rendah jika ingin meningkatkan keterampilan tendangan lurus Pencak silat dapat menggunakan kedua metode latihan peregangan baik skipping rope maupun hop jump.

3. Bagi pesilat yang memiliki kemampuan gerak (motor ability) tinggi, hasil keterampilan tendangan lurus pencak silat melalui penerapan metode latihan skipping rope (A1) lebih baik daripada metode latihan hop jump (A2).
Dikatakan bahwa kedua metode ini mempunyai tujuan yang sama yaitu meningkatkan hasil keterampilan tendangan lurus pencak silat, tetapi masing-masing memiliki perbedaan dalam segi pelaksanaannya. Metode latihan skipping rope dalam pelaksanaannya menekankan pada latihan lompat-lompat. Metode latihan yang dilakukan berpasangan atau dengan bantuan teman akan memudahkan pelaksanaan serta memunculkan motivasi dari pelaku.

Bagi pesilat yang memiliki kemampuan gerak (motor ability) tinggi hal yang demikian justru akan dapat mengembangkan kemampuannya terhadap pencapaian peningkatan keterampilan, karena mereka lebih tertarik untuk melakukan yang lebih jauh.

Sedangkan metode latihan hop jump dalam pelaksanaannya, menekankan pada latihan lompat tanpa alat. Dengan kata lain pesilat yang melakukan metode latihan hop jump tidak dipengaruhi oleh faktor eksternal. Bagi pesilat yang memiliki kemampuan gerak tinggi, latihan tersebut merupakan kegiatan yang biasa serta tidak mempunyai tantangan yang tinggi, karena menurutnya latihan tersebut sangat mudah dan sederhana sehingga tidak menimbulkan motivasi yang tinggi serta unsur kompetisi sangat kecil dalam meningkatkan kemampuan gerak, dengan demikian hasil yang akan dicapai juga tidak seperti yang diharapkan. Dengan kata lain, berlatih dengan penerapan metode latihan hop jump bagi pesilat yang memiliki kemampuan gerak (motor ability) tinggi kurang menimbulkan unsur motivasi serta kompetisi.

Hasil analisis gerak di atas diperkuat oleh hasil uji lanjut kelompok kemampuan gerak (motor ability) tinggi yang dilatih dengan metode latihan skipping rope (P1) dibandingkan dengan kelompok kemampuan gerak (motor ability) tinggi yang dilatih dengan metode latihan hop jump (P2), hasilnya; $\mathrm{Q}_{\text {hitung }}=5,26>\mathrm{Q}_{\text {tabel }}=3,79$. Dengan 
kata lain bahwa bagi pesilat yang memiliki kemampuan gerak tinggi, keefektifan metode latihan skipping rope (F = 42 dan $\mathrm{sd}=3,65)$ lebih baik secara nyata dibandingkan dengan metode latihan hop jump $($ 羁 $=35,5$ dan $\mathrm{sd}=3,55$ )

Dengan demikian berdasarkan pembahasan hasil penelitian, maka dapat direkomendasikan bahwa bagi pesilat yang memiliki kemampuan gerak tinggi, metode latihan skipping rope lebih cocok diterapkan dalam meningkatkan keterampilan tendangan lurus Pencak silat.

\section{Bagi pesilat yang memiliki kemampuan gerak (motor ability) rendah, hasil keterampilan tendangan lurus Pencak silat melalui penerapan metode latihan hop jump (A2) lebih baik daripada metode latihan skipping rope (A1).}

Dikatakan bahwa kedua metode latihan ini mempunyai tujuan yang sama yaitu meningkatkan hasil keterampilan tendangan lurus Pencak silat, tetapi masing-masing memiliki perbedaan dalam segi pelaksanaannya.

Metode latihan hop jump dalam pelaksanaannya, menekankan pada latihan tanpa alat. Metode latihan ini dilakukan tanpa bantuan teman atau partner, artinya melakukan suatu lompatan berdasarkan keinginan serta kemampuannya sendiri. Dengan kata lain pesilat berlatih sesuai irama dan kemampuannya sendiri tanpa kontrol batas waktu serta kemampuannya, dan hal ini tidak diipengaruhi oleh faktor lingkungan. Bagi pesilat yang memiliki kemampuan gerak rendah, latihan seperti ini merupakan kegiatan yang sangat disenangi, karena menurutnya latihan tersebut gerakan-gerakannya tidak terlalu sulit sehingga pesilat melakukan hanya menurut keinginannya saja. sehubungan dengan itu, hasil yang diharapkan akan dapat tercapai. Dengan kata lain, berlatih dengan penerapan metode latihan hop jump bagi pesilat yang memiliki kemampuan gerak (motor ability) rendah lebih merangsang timbulnya gairah untuk mencapai tingkat otomatisasi gerakan tendangan lurus Pencak silat. Sedangkan berlatih dengan penerapan metode latihan skipping rope pesilat yang memiliki kemampuan gerak (motor ability) rendah, kurang merangsang timbulnya gairah serta motivasi dalam usaha pencapaian otomatisasi gerakan tendangan lurus Pencak silat.

Hasil analisis gerak di atas ditunjang oleh hasil uji lanjut kelompok kemampuan gerak (motor ability) rendah yang dilatih dengan metode latihan hop jump (P4) dibandingkan dengan kelompok kemampuan gerak (motor ability) rendah yang dilatih dengan metode latihan skipping rope (P3), hasilnya; $\mathrm{Q}_{\text {hitung }}=2,25<\mathrm{Q}_{\text {tabel }}=$ 3,79 . Dengan kata lain bahwa bagi pesilat yang memiliki kemampuan gerak (motor ability) rendah, metode latihan hop jump $=33,14$ dan $\quad \mathrm{sd}=5,33$ ) dan metode latihan skipping rope $($ : 30,36 dan $\mathrm{sd}=3,41$ ) tidak memberikan keefektifan hasil yang signifikan terhadap keterampilan tendangan lurus Pencak silat.

Dengan demikian berdasarkan pembahasan hasil penelitian, maka bagi pesilat yang memiliki kemampuan gerak (motor ability) rendah, kedua metode latihan cocok diterapkan dalam meningkatkan keterampilan tendangan lurus Pencak silat.

\section{KESIMPULAN}

Hasil keterampilan tendangan lurus bagi kelompok pesilat yang dilatih dengan metode latihan skiping rope secara keseluruhan lebih baik dibandingkan dengan kelompok pesilat yang dilatih dengan model latihan hop jump. Bagi pesilat yang memiliki kemampuan gerak (motor ability) tinggi, hasil keterampilan tendangan lurus melalui penerapan metode latihan skiping rope lebih baik dibandingkan dengan model latihan hop jump. Bagi pesilat yang memiliki kemampuan gerak (motor ability) rendah, hasil keterampilan tendangan lurus melalui 
penerapan metode latihan hop jump lebih baik dibandingkan dengan metode latihan skiping rope. Terdapat interaksi antara metode latihan dengan kemampuan gerak (motor ability) terhadap hasil keterampilan tendangan lurus pencak silat.

\section{SARAN}

Dalam upaya untuk meningkatkan keterampilan tendangan lurus pada pencak silat para pesilat, maka perlu diberikan metode latihan yang sesuai dengan faktor internal individu seperti kemampuan gerak (motor ability). Mengingat pentingnya penerapan metode latihan ini, maka bagi pelatih pencak silat dalam memberikan metode latihan sebaiknya mengetahui terlebih dahulu kemampuan gerak (motor ability) dari pesilat. Bagi pesilat yang memiliki kemampuan gerak (motor ability) tinggi, disarankan agar dalam melatih keterampilan tendangan lurus pada pencak silat menggunakan metode latihan skiping rope. Bagi pesilat yang memiliki kemampuan gerak (motor ability) rendah, disarankan agar dalam melatih keterampilan tendangan lurus pada pencak silat menggunakan metode latihan hop jump.

\section{DAFTAR PUSTAKA}

Agus Sutisna, "Pengaruh Gaya Mengajar dan Motor Educability Terhadap Ketrampilan Rangkaian Gerak Dasar Pencak Silat 1A Perguruan Candra Birawa" tesis, Jakarta: PPs Universitas Negeri Jakarta, 2010

Allen L. Edwards, Experimental Design in Physical Research. Fifth Edition, New York: Harper \& Row, Inc, 1985.

Anne Shumway Cook dan Marjorie H. Woollacott., Motor Control Theory and Practical
Applications, Amerika:

Lippincott Williams \&

Wilkins, 2001

Bahmid Hasbullah, “ Pengaruh

Gaya Mengajar dan

Kemampuan Motorik

Terhadap Hasil Belajar

Ketrampilan Forehand

Drive Tenis Mini"

Disertasi , Jakarta: PPs

Universitas Negeri

Jakarta, 2008.

Notosoejitno, Khasanah Pencak

Silat Jakarta; Agung

Press, 1997

PB.IPSI,

Peraturan

Pertandingan Pencak Silat.

Jakarta: 2012

R. Kotot Slamet Hariyadi, Teknis

Dasar Pencak Silat

Tanding, Jakarta: Dian

Rakyat, 2003.

Richard A.Magil, Motor

Learning and Control, New

York: Mc Graw Hill, 2011

Richard A. Magill, Motor Learning, Conceps and Aplication, IOWA: WM.

C.Brown Publisher, 1985.

Robert N. Singer, The Learning of Motor Skill, New

York: Macmillan

Publishing Co.Inc, 1982.

Rusli Lutan, Belajar

Keterampilan Motorik

Pengantar Teori dan

Metode, Jakarta:

Depdikbud, 1998.

Rusli Lutan, Belajar

Keterampilan Motorik

Pengantar Teori dan

Metode, Bandung : 1992

Winarn, M.E. Metodologi

Penelitian dalam

Pendidikan Jasmani,

Malang : Media

Cakrawala Utama 